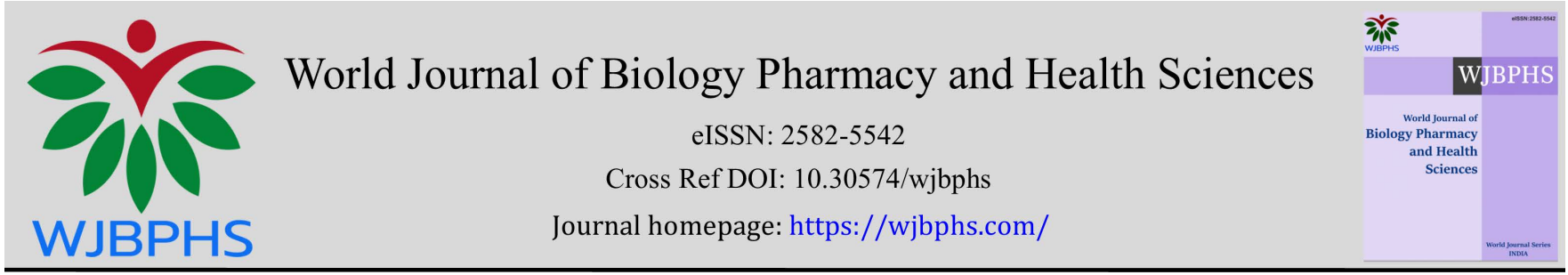

(RESEARCH ARTiCLE)

\title{
The effect of motivation on the regularity of paying contributions for independent National Health Insurance (NHI) participants post policy of increasing contributions in Muna District, Southeast Sulawesi Province
}

\author{
Suhadi *, Nani Hendryani and I Made Christian Binekada \\ Public Health Study Program at Halu Oleo University Kendari, Indonesia. \\ World Journal of Biology Pharmacy and Health Sciences, 2022, 09(02), 033-039 \\ Publication history: Received on 10 January 2022; revised on 14 February 2022; accepted on 16 February 2022
}

Article DOI: https://doi.org/10.30574/wjbphs.2022.9.2.0041

\begin{abstract}
Weak public participation in the payment of NHI contributions has been identified as a major obstacle to the successful implementation of long-term NHI. Increasing voluntary health insurance coverage for low-income communities is a challenge for the government. The purpose of this study was to determine the effect of motivation on the regularity of paying dues for independent NHI participants after the increase in contributions in Muna Regency, Southeast Sulawesi. The type of research used is quantitative research using a cross sectional study design. The size of the sample in this study were 98 respondents. Methods Data collection is done by interview and observation in the field. Implementation of Univariate and Bivariate data analysis. The method of presenting data in the form of a frequency distribution is accompanied by a narration. The results showed that there was an influence of motivation on the regularity of paying dues for independent NHI participants after the contribution increase policy in Muna Regency, Southeast Sulawesi Province, with a value of $p=0.046(p<0.05)$. Conclusion; there is a motivational effect on the regularity of paying dues for independent NHI participants after the policy of increasing the contribution. Suggestion; It is necessary to develop an educational strategy to increase participants' understanding and motivation so that they are aware of paying the dues of independent NHI participants on a regular basis.
\end{abstract}

Keywords: Motivation; Regularity; Paying; Contributions; NHI

\section{Introduction}

Currently the main problem in public health, where the government as the organizer of government and international health organizations around the world is a challenge in terms of health financing. For most countries, this challenge is due to weak health financing policies. As for the recommended strategy to deal with issues related to international health policy, the implementation of various program interventions including the formulation of health insurance policies to maintain public health [1]. The World Health Organization encourages all countries to develop health insurance for the entire population [2]. National health insurance is an important way to achieve an increase in public health status by ensuring that all people can receive quality health services according to their needs and desires, without experiencing financial difficulties [3]. To avoid cost constraints, an insurance system was developed in an effort to achieve Universal Health Coverage (UHC) [4]. At least 150 million people every year in low- and middle-income countries suffer from health expenses and 100 million people or the equivalent of three people every second become poor due to self-financing for their health [3].

Currently in Indonesia, UHC is known as the National Health Insurance. NHI is organized by the Health Social Security Administrator (SSA). NHI is part of the National Social Security System with a social health insurance mechanism. NHI

\footnotetext{
${ }^{*}$ Corresponding author: Suhadi

Public Health Study Program at Halu Oleo University Kendari, Indonesia.
} 
membership is mandatory as stated in Law Number 40 of 2004 concerning the National Social Security System. Why people are required to have health insurance, the purpose is so that all Indonesians are protected in an insurance system and to meet the basic needs of proper public health that is given to everyone who has paid contributions or contributions paid by the government [5].

One way to make UHC successful is to increase the number of participation-of informal sector workers. Empirical studies state that the weak participation of people in health insurance is the low income of people in low-income countries. Increasing voluntary health insurance coverage for low-income people is a challenge for the government. For the government, knowing this, the government can make a policy that can cover all people to become participants in the National Health Insurance. The NHI contribution is the amount of funds that must be paid by each NHI participant, whether it is an Employer Participant, Regional Government, or Central Government consistently in the health insurance program. Based on Law no. 24 of 2011 concerning the National Health Organizing Body, the collection of NHI contributions and their development which is managed by SSA Health is a mandated fund belonging to all participants. The funds are used for payment of benefits to participants and operational financing of the implementation of the health insurance program [6].

Currently, the number of SSA Health participants in Indonesia as of December 2019 reached 224,146,972 people. The NHI membership consists of Contribution Assistance Recipients and Non-Contribution Assistance Recipients. Participants receiving the NHI Contribution Assistance include people who are classified as poor and needy whose contributions are paid by the government, while participants who are not recipients of Contribution Assistance are participants who are not classified as poor and cannot afford [7]. One participant who is not a Contribution Assistance Recipient is an independent worker who earns income from his own business, so when they become a NHI participant, they must pay a monthly contribution. In Indonesia as of December 2019, the number of independent participants has reached $30,239,122$ people [8].

The amount of the contribution is the key to sustainability, the quality of Health Insurance, the impact on the new impoverishment, and increasing the productivity of the population. If the contributions are determined without careful calculation, or only by agreement, then there is a threat that SSA Health will not be able to pay for health facilities, guarantees are not available, and the people no longer trust the state. The amount of the contribution must be-firstly enough to pay for health services of good quality, secondly enough to fund SSA Health operations with good quality at a reasonable economic price, thirdly, technical reserve funds are available in case of high claims at any time, fourthly, funds for program development, research are available. operations, or new treatments [9]. As a result of the increase in fees, not a few NHI participants have proposed lowering their service class. According to the President Director of SSA Health, 372,924 participants who dropped out of service class. A total of 153,466 participants or 3.5\% dropped from class I and 209,458 people or 3.3\% dropped from class II [10].

In Southeast Sulawesi Province, the number of NHI participants, both Contribution (BC) and non-BC/independent recipients has reached 2,409,474 people. The number of BC participants funded by the State Revenue and Expenditure Budget was 1,209,244 people. The BC funded by the district/municipality Regional Revenue and Expenditure Budgets was recorded at 547,697 people. BC funded by the Provincial Revenue and Expenditure Budget was recorded at 36,516 people. Wage Recipients (WR) for civil servants were 308,417 people. WR Private employees recorded as many as 90,282 people. Non-Wage Recipient Workers (NWRW) recorded as many as 180,324 people and Non-Workers (NW) recorded as many as 36,994 people [11]. In the Muna Regency area, the number of NHI participants as of December 31, 2019 was recorded at 225,628. BC funded by the State Revenue and Expenditure Budget was recorded at 100,850 people. BC funded by the Regency/City Regional Revenue and Expenditure Budget was recorded at 81,272 people. BC funded by the Provincial Revenue and Expenditure Budget was recorded at 2,486 people, while non-BC,WR for Civil Servants were recorded at 30,014 people. WR for private registered employees is 777 , PBPU is 6,255 and NW is 3,974 [12].

From the initial data collection in the field, several problems occurred in connection with the regularity of payments, including; some participants are still in arrears in paying NHI contributions, payments are not on time, there are complaints about NHI contributions that are burdensome after the contribution increase policy, some participants feel they are no longer able to pay during the current pandemic, the reason is that their income is not enough to pay NHI contributions, the reason is they don't have fixed income and so on. The purpose of the study was to determine the effect of motivation on the regularity of paying dues among NHI Independent participants after the Contribution Increase Policy in Muna Regency, Southeast Sulawesi Province. 


\section{Material and methods}

This type of research is a quantitative research using a cross sectional study design. The cross-sectional study design is a research design by measuring or observing at the same time measuring the independent and dependent variables. This research was carried out in Muna Regency in April-May 2021. The research sample using the Slovin formula was 98 people. By using purposive side. Purposive sampling is a technique of determining the sample based on the consideration of the researcher by determining the special characteristics that are in accordance with the research objectives so that it is expected to be able to answer research problems. The method of data collection is done by means of interviews and field observations. Data analysis was carried out by Univariate and Bivariate, while the presentation of data was carried out in the form of a frequency distribution table with explanations.

\section{Results and discussion}

\subsection{Univariate Analysis}

\subsubsection{Motivation}

Motivation is defined as an emotional impulse that arises from within a person to do something in response to reactions that occur outside of humans. The distribution of respondents based on motivation for independent NHI participants after the contribution increase policy in Muna Regency, Southeast Sulawesi Province, is presented in table 1.

Table 1 Distribution of respondents based on motivation for independent NHI participants after the contribution increase policy in Muna Regency, Southeast Sulawesi Province

\begin{tabular}{|l|c|c|}
\hline Motivation & Amount (n) & Percentage (\%) \\
\hline Tall & 30 & 31 \\
\hline Low & 68 & 69 \\
\hline Total & 98 & 100 \\
\hline \multicolumn{2}{|c|}{ Source: Primary Data Year 2021. }
\end{tabular}

Table 1 shows that out of 98 respondents (100\%), most respondents have low motivation in paying dues, namely 68 respondents (69\%), and a small proportion of respondents have high motivation in paying dues, only 30 respondents $(31 \%)$.

\subsubsection{Regularity of Paying Dues}

Regularity in paying NHI contributions is defined as the regularity or timeliness of payment of National Health Insurance contributions made by the respondent, where the payment time has been determined no later than the 10 th of each current month as stipulated in the Presidential Regulation of 2021. The distribution of respondents is based on the regularity of paying contributions independent NHI participants are presented in table 2.

Table 2 Distribution of respondents based on regularity in paying contributions to independent NHI participants after the policy of increasing contributions in Muna Regency, Southeast Sulawesi Province

\begin{tabular}{|l|c|c|}
\hline Regularity of Paying Dues & Amount (n) & Percentage (\%) \\
\hline Regular & 44 & 45 \\
\hline Irregular & 54 & 55 \\
\hline Total & 98 & 100 \\
\hline \multicolumn{2}{|c|}{ Source: Primary Data Year 2021 }
\end{tabular}

Table 2 shows that of the 98 respondents (100\%), most of the respondents are not regular in paying NHI contributions, namely 54 respondents (55\%), and a small proportion of respondents who are regular in paying contributions are 44 respondents (45\%). 


\subsection{Bivariate Analysis}

\subsubsection{The effect of motivation on the regularity of paying dues for independent NHI participants}

Table 3 Effect of motivation on regularity in paying dues for independent NHI participants after the policy of increasing contributions in Muna Regency, Southeast Sulawesi

\begin{tabular}{|c|c|c|c|c|c|c|c|}
\hline \multirow{3}{*}{ Motivation } & \multicolumn{4}{|c|}{ Regularity of Paying Dues } & \multirow{2}{*}{\multicolumn{2}{|c|}{ Amount }} & \multirow{3}{*}{ P-Value } \\
\hline & \multicolumn{2}{|c|}{ Regular } & \multicolumn{2}{|c|}{ Irregular } & & & \\
\hline & $\mathrm{n}$ & $\%$ & $\mathrm{n}$ & $\%$ & $\mathrm{n}$ & $\%$ & \\
\hline Tall & 18 & 60 & 12 & 40 & 30 & 100 & \multirow{3}{*}{0,046} \\
\hline Low & 26 & 38 & 42 & 62 & 68 & 100 & \\
\hline Total & 44 & 45 & 54 & 55 & 98 & 100 & \\
\hline
\end{tabular}

Table 3 shows that of the 30 respondents (100\%) who have high motivation, there are 18 respondents (60\%) who regularly pay NHI contributions, and there are 12 respondents (40\%) who do not regularly pay NHI contributions. Meanwhile, of the 68 respondents (100\%) who have low motivation, there are 26 respondents (38\%) who regularly pay NHI contributions and 42 respondents (62\%) who do not regularly pay NHI contributions independently. Based on the results of the chi square test, the value of $p=0.046(p>0.05)$ means that Ho is rejected. This shows that there is a motivational influence on the regularity of paying NHI contributions for independent participants after the contribution increase policy in Muna Regency, Southeast Sulawesi Province.

Until now, the number of SSA health memberships in Indonesia continues to increase despite the fact that the increase in the number of NHI memberships is not always accompanied by participant compliance in paying contributions. Note The development of membership coverage shows that in 2018 there were 208.054,199 people and as of May 31, 2019 there had been an increase to 222,02,996 people. When viewed from the comparison of these data, when calculated from 2016 to 2019, there was an increase in the number of participants by $66.3 \%$ or an addition of 88,579,343 people [13]. Nationally, in 2018, the average participant contribution was Rp.394,009 per year, while the amount of health insurance claims was Rp.453,232 per year, there was a difference of Rp.59,223 per participant per year [14]. Since the beginning of its implementation, the NHI program has continued to experience a budget deficit. In fact, the budget deficit is predicted to reach IDR 28 trillion by the end of 2019 [13].

According to SSA Health, the budget deficit is caused by the high number of people suffering from chronic diseases so that the cost of health services continues to increase. The high health burden is not matched by an adequate amount of contributions. If the problem of the budget deficit is not immediately addressed, it will have an impact on the decline in the quality of health services, the trust of service providers and service users so that public welfare will decrease. If the budget deficit problem is not immediately addressed, then Universal Health Coverage will be difficult to achieve. The problem of the NHI budget deficit at the national and regional levels has almost the same pattern, while the cause of the problem is that the contribution of NHI contributions is low, far below the number of NHI claims submitted by health facilities and the low compliance of the community in paying NHI contributions, especially independent participants [15].

National health insurance as a health protection program launched with the aim of providing benefits for maintaining and protecting public health in meeting basic health needs which is given to everyone who has paid dues or whose contributions are paid by the government. Operationally, the implementation of the NHI system is contained in Government Regulations and Presidential Regulations. Participants who take part in the health insurance program will receive health care and basic health services. This National Health Insurance is managed by the Health Social Security Administering Body as stipulated in Law Number 24 of 2011 and has been operating since January 1, 2014. All Indonesian residents are required to become participants in the health insurance managed by SSA, including foreigners who have worked for a minimum of six months in Indonesia and have paid dues [16].

Motivation that arises in a person as a result of the interaction between behavior and the environment so that it can increase, decrease or maintain behavior. Motivation means an impulse from within humans to act or behave. The theory of motivation according to Maslow, states that motivation is based on the level of needs arranged according to the priority of strength [17]. According to Kertayasa (2010), if the needs at the lower level have been met, then this need 
will lead to the need to meet higher needs [18]. Thus, based on the above theory, it can be assumed that when the National Health Insurance program is used as the main need in a person's life, NHI participants are expected to have the awareness to pay National Health Insurance contributions regularly.

Based on the results of the study as shown in table 3, it was found that respondents who had low motivation were more likely to irregularly pay NHI contributions than those who regularly paid independent NHI contributions. Meanwhile, respondents who have high motivation are more likely to regularly pay independent NHI contributions than those who do not regularly pay independent NHI contributions. These findings indicate that low motivation is the cause of the low regularity of paying NHI contributions. Independent NHI participants who have high motivation and are regular in paying NHI contributions generally come from people who have a fixed income, so they tend to regularly make independent NHI contributions. However, respondents who have high motivation but are not regular in paying NHI are caused by their non-permanent income.

Currently, the world, including Indonesia, is facing the Covid-19 pandemic, which for the last 2 years has had a major impact on life, including health. The implementation of restrictions on community activities that apply is the biggest challenge faced by the community during the Covid-19 pandemic, this has an impact on people's income where people cannot work as usual. As a result, people experience a decrease in income. The decrease in people's income causes a person to be unable to pay the NHI contributions independently. Barriers to obtaining sufficient additional income are not only experienced by independent workers, other sectors are also experiencing this impact. With the increasing number of people who do not regularly pay NHI contributions, it will reduce the amount of NHI financial income managed by SSA, the long-term impact is that health facilities will experience disruption of funding sources.

A person's motivation is one of the predisposing factors that will encourage someone to behave or act in accordance with their understanding and belief in health services. With the motivation from within humans, it becomes a strength for themselves to respond well to take action according to their understanding so that the person can perform or comply with the payment of independent NHI contributions. According to Iriyana, a person's desire to pay health contributions is closely related to the motivation of that person. Motivation can be triggered by various things, both positive and negative. Positive motivation in paying health contributions may arise when someone really wants to get health insurance, for example when they are sick or when their income is high. Meanwhile, negative motivation for certain reasons, for example, participants do not know clearly about the rules, conditions and benefits received [19].

Based on the statistical test results, it is obtained that the value ( $\mathrm{r}$ ) $=0.202$ means that the correlation is moderate or sufficient, $p=0.046$ ( $p<0.05$ ), so, Ha is accepted, it can be interpreted that there is an influence of motivation on the regularity of paying contributions to independent NHI participants after the policy increase in fees in Muna Regency, Southeast Sulawesi Province. The results of this study are in line with research [20], [21], which says that there is a significant relationship between motivation and compliance in paying SSA Independent contributions. However, the results of this study are not in line with research conducted by [22] which said that respondents with high motivation who obediently pay NHI Independent contributions are $31.6 \%$, this is because respondents have an awareness that maintaining health is very important in order to stay healthy and can work well. The results of the chi square statistical test show that the level of motivation has a relationship with compliance with paying NHI Independent contributions.

The findings in the field show that respondents who have low motivation are more in number than those who have more high motivation, this is because there is an element of income that also affects the regularity of paying where generally respondents do not have sufficient funds to pay NHI contributions, this is related to low income due to uncertain sources of income each month. On the other hand, there is still an assumption that they feel it is useless to make payments even though they are not sick, but when they are sick they will be forced to pay NHI contributions in order to get health services. However, for respondents who have high motivation and pay NHI contributions, this is due to the availability of sufficient funds from their sources of income and their good understanding of health services.

Based on the findings on some of the problems above, the Muna Regency government should make efforts to develop programs to help the community through social assistance. Relevant agencies should be able to educate, socialize and disseminate information about NHI in an effort to increase people's motivation to create a spirit of community compliance in paying NHI contributions. In the implementation of socialization activities by the SSA and the district government, mainly to people who are often in arrears.

Conceptually, services have a pattern of demand for services in accordance with the needs and desires of the community. If the price of the goods offered is high enough, it makes people delay buying or paying even though their motivation is quite high, but the perception of changing the amount of contributions will change people's willingness to pay NHI contributions. If the health services received by the community have caused disappointment or are not in line with their 
expectations, then the community will not regularly pay NHI contributions. On the other hand, even though the price of goods is high and balanced with high utilization of health services, the community will have the motivation to pay. However, the whole community should have good motivation to pay contributions, in order to create and achieve sustainable Universal Health Coverage in the future [23].

\section{Conclusion}

There is an influence of motivation on the regularity of paying dues for independent NHI participants after the contribution increase policy in Muna Regency, Southeast Sulawesi Province with a value of $p=0.046(p<0.05)$.

\section{Suggestion}

It is necessary to develop an educational strategy to increase participants' understanding and motivation so that they are aware of paying the dues of independent NHI participants on a regular basis.

\section{Compliance with ethical standards}

\section{Acknowledgments}

The author would like to thank the Dean of the Faculty of Public Health, Halu Oleo University, who has provided support to the writing team so that this research can be carried out properly. Furthermore, the team of authors would like to thank all those who have helped until the end of this research.

\section{Author contribution}

Suhadi, Nani Hendryani, and I Made Christian Binekada as designers, implementers of research and preparation of reports. Suhadi as a reviewer of the report manuscript. Nani Hendryani as data collector, analyzer and interpreter of data. All authors read and agree to the Final Report.

\section{Disclosure of conflict of interest}

All authors state that this research was conducted without any conflict of interest.

\section{Statement of informed consent}

All informants/respondents involved in this study have stated their consent as informants/respondents to be interviewed and provided information/information in accordance with research needs.

\section{References}

[1] Kumi kyereme A, et al. Barriers and motivations for health insurance subscription in Cape Coast , Ghana : a qualitative study, Arch. Public Heal. 2017; 75(24): 1-10.

[2] Yustina EW, Budisarwo Y. Health Insurance Law (A Study of the Welfare State Concept in the Implementation of Health Insurance). Semarang: Soegijapranata Unika. 2020.

[3] Hasibuan R. Overview. Response of NHI participants. Regarding Increase. Premiums at. Two Medan City Health Center In 2019, Contag science. J. of Public Health. And Coastal Heal. 2020; 1(2): 108-120.

[4] WHO. A Broad Spectrum of Health Challenges-Selected Issues, 2018.

[5] Esty AB. Study of Refer back Program (PRB) at Balung Regional Hospital Jember Regency, Jember University. 2017.

[6] Macha J. Der konfessionelle Factor in der deutschen Sprachgeschichte der Frühen Neuzeit, 2014.

[7] Fardiansyah A, et al. Factors Related to Compliance with Paying NHI Contributions to Independent Participants in the Inpatient Installation of RSUD Sidoarjo, Hospital Majapahit 2021; 13(2): 92-103.

[8] Pratiwi AN. Factors Affecting Regularity in Paying Contributions to National Health Insurance Participants in the Independent Participant Category, Adm. and Wisdom. health. 2016; 53(9). 
[9] Syakhila I. Factors Relating to ATP and WTP With Determination of the Class of BPJS Health Contributions, Wind. Public Health. J. 2021; 1(5): 427-436.

[10] BPJS KM. Muna Regency JKN Participation Data in 2020, Raha. 2020.

[11] BPS Muna. Muna Regency in Numbers, Raha. 2020.

[12] Muna Health Office. Profile of the Muna District Health Office in 2019. Raha 2020.

[13] BPJS RK. Health BPJS Profile Year. 2020; 01(04): 382-393.

[14] President RI. Presidential Regulation concerning the Second Amendment to Presidential Regulation Number 82 of 2018 concerning National Health Insurance. Indonesia: State Secretariat of the Republic of Indonesia. 2020; 42.

[15] Aidha C.C. National Health Insurance Deficit. Proposed Alternative for Sustainable Funding, Jakarta. 2020.

[16] President RI. Presidential Regulation of the Republic of Indonesia Number 82 of 2018 concerning Health Insurance. Jakarta: State Secretariat of the Republic of Indonesia. 2018.

[17] Mokolomban C, et al. Factors Related to Compliance of Independent Participants in Paying National Health Insurance Contributions in the Work Area of Ranotana Weru Health Center Manado City, J. Public health 2019; 7(4): 1-10.

[18] Mendari AS. The application of Maslow's hierarchy of needs theory in increasing student learning motivation, Widya War. J. scientific University Widya Mandala Catholic Madiun, XXXIV. 2010; (1): 82-91.

[19] Umrohadin II. Review of Islamic Law on the Premium Payment System and Fund Management by the Health Social Security Administration, Hasanuddin University. 2016.

[20] Nabila W, Latifah AN. Factors Affecting Compliance of Independent Participants Paying NHI Contributions in Benda Baru Village, J. Medical. And Health. 2020; 1(6) 27-36.

[21] Widyanti N. Factors Relating to Compliance with Paying NHI Independent Contributions to Patients at Labuang Baji Hospital, Makassar City, J. Dep. Adm. policy. Health, fac. health. Society, University Hasanuddin, Makassar. 2018; 3(2).

[22] Hasan N, Batara AS. Factors Related to Compliance with Paying NHI Contributions to Independent Participants in the Work Area of the Tamamaung Health Center Makassar City in 2020, Wind. Public Health. J. 2020; 1(4): 382-393.

[23] Pangestika VF, et al. Factors Related to Informal Sector Participation in Independent Health Social Security Administration Agency in Poncol Village, East Pekalongan District, Pekalongan City, J. Public Health, 2017; 5(3): $39-49$. 